\title{
Production of Microalgae Biomass Using Vinasse as Cultivation Medium.
}

\author{
W. S. Abou El- Kheir, A. H. Farag and S. AbdelKader \\ Botany Department, Women's College, Ain Shams University, Cairo, Egypt.
}

\begin{abstract}
:
Microalgae are one of the potential food sources in the future. Many authors have investigated the potential of wastewater as cultivation medium for microalgae, but utilization of sugarcane digested vinasse as cultivation medium for algae has not yet been reported. The purpose of this study was to test the potential of vinasse as an alternative source of nutrients for culturing microalgae. One pure strain of a green alga (Chlorella vulgaris) and two pure strains of blue green algae (Spirulina platensis and Nostoc commune) were used for this purpose. The three microalgae were grown on six various concentrations of vinasse from $0.01 \%$ to 0.03 and from $0.1 \%$ to $0.3 \%$ for 21 and 35 days. The present investigation showed that digested vinasse contained ammonia $\left(\mathrm{NH}_{3}\right)$, nitrate $\left(\mathrm{NO}_{3}\right)$, phosphate $\left(\mathrm{PO}_{4}\right)$, Calcium $(\mathrm{Ca})$, Magnesium $(\mathrm{Mg})$, Sodium $(\mathrm{Na})$, Potassium $(\mathrm{K})$ and high Electron Conductivity (EC). The highest productivity of biomass by Chlorella vulgaris (368 $\mathrm{x}$ $10^{6} \mathrm{mg} / \mathrm{L}$ ) was observed when using $0.3 \%$ vinasse medium, by Nostoc commune (1400 $\mathrm{x}$ $\left.10^{6} / \mathrm{L} \mathrm{mg} / \mathrm{L}\right)$ when using $0.01 \%$ medium and by Spirulina platensis $\left(200 \times 10^{6} \mathrm{mg} / \mathrm{L}\right)$ when using $0.02 \%$ medium. The period of 35 days was better than 21 days for the growth of all examined species. No algal growth was observed when using higher concentrations of vinasse (from $1 \%$ to $6 \%$ ). The present results show that it is possible to integrate the culturing of microalgae with the sugarcane industry product (vinasse) by means of anaerobic digestion.
\end{abstract}

Key words: Phytoplankton, vinasse, cultivation media, industrial effluents.

\section{Introduction:}

Industrial effluents contain environmental pollutants such as organic and inorganic compounds, acids, suspended solids, and other materials. When untreated effluents are discharged into the environment, they disrupt the ecological area of living organisms. To gain a better understanding of the impact of effluents on ecosystems, adequate laboratory pilot tests should be carried out to determine the toxic action of industrial effluent on individual organisms. The effluent of sugar industry normally comes from molasse which is diluted with water and allowed to ferment under controlled temperature and $\mathrm{pH}$ with the addition of sulfate and urea. After fermentation, the liquid portion is distilled to recover alcohol and the residual liquid (known as spend wash) becomes the main polluting effluent. (Sreedevi, 2007)

Corresponding : shymaaqader@yahoo.com 
Microalgae are able to accumulate nutrients from wastewater and therefore, have the potential to play an important remediation role (Ruiz-Marín et al., 2010). Simultaneously, the cultivation of microalgae can provide a useful source of biomass. It has been estimated that about $30 \%$ of the current world algal production is sold for animal feed application, i.e., aquaculture and poultry feed (Coca et al., 2014).

Vinasse a byproduct from molasses fermentation factories, it is known to be corrosive and possess a foul smell. It is difficult to dispose of involves a severe environmental concern and a threat to watercourse quality (Coca et al., 2005 and Mohana et al., 2009). The composition of vinasse varies greatly; it depends on whether molasses of sugarcane juice or a mixture of product used for distillation. It is also affected by agronomic factors in the growth of the cane, notably soil fertility and fertilizer application (Meyer et al., 2011).

Vinasse is characterized by extremely high chemical oxygen demand (60-100 g/L COD) and biochemical oxygen demand (30-60 g/L BOD) (Satyawali and Balakrishnan, 2008; Mohana et al., 2009; Coca et al., 2014).

Tejada (2010) mentioned that vinasse contains potassium (K) and calcium (Ca). Tejada and Gonzalez (2005) reported that vinasse may also have high concentrations of micronutrients and heavy metals such as iron (Fe), copper (Cu), manganese ( $\mathrm{Mn}$ ) and zinc ( $\mathrm{Zn}$ ). The organic matter content of vinasse is very high and as this contains most of the nitrogen fraction, it is necessary to supplement with inorganic nitrogen fertilizer and also phosphate where required (Meyer et al., 2011).

The content of vinasse which have mentioned above lead for using vinasse as a culture medium, or as an inexpensive supplement to media, to produce biomass. The use of vinasse in the formulation of culture media may reduce production costs due to the use of an organic residue as a cheap nutrient source (Victor et al., 2010).

Information available in the literature suggests that the major organic components of sugarcane vinasse are glycerol, lactic acid, ethanol and acetic acid (Dowd et al., 1994; Decloux and Bories, 2002), whereas sugar beet vinasse also contain glycerol and their main compound is nitrogen- rich betaine (Troccon and Demarquilly, 1989; Decloux and Bories, 2002).

In addition to these low molecular weight compounds, vinasse may contain melanoidins and phenolic compounds, which can inhibit or reduce the activity of microorganism (FitzGibbon et al., 1998). Vinasse contains also cellulose and hemicellulose (Benke et al., 1998 and Parnaudeau et al., 2007).

Singh and Dhar (2006), Satyawall and Balakrishnan (2008) and Andres et al. (2014) mentioned that vinasse is characterized by low $\mathrm{pH}$, strong smell, a dark brown color which difficult for the photosynthesis of native aquatic flora, therefore water quality deteriorates and is detrimental to life exists therein. It is has high concentration of solids thereby making 
it a serious threat to water quality if released untreated (Satyawali and Balakrishanan 2008; Coca et al., 2014).

However the chemical composition of vinasse in fact depends on numerous factors such as the sugarcane variety, the soil type and the process of preparing the alcohol (Parnaudeau et al., 2008; Soobadar and Ng Kee Kwong, 2012).

The irrigation with vinasse can improve soil fertility (Silva, 2009). Vinasse can be recycled and reused through the cultivation of microalgae, besides the application in the irrigations of sugar cane crop. This would also qualify the cultivation of microalgae as a clean development mechanism to reduce the levels of greenhouse gases (Cenciani et al., 2011).

Digested vinasse can be used for the production of biodiesel and other compounds, whilst the excess $\mathrm{CO}_{2}$ produced in the ethanol fermentation can be used to stimulate algal growth. During algae cultivation, the $\mathrm{pH}$ of the culture medium has a strong tendency to increase, recycling of the spent culture medium or the concentrated algae suspension to the anaerobic digester treating vinasse was considered an option for $\mathrm{pH}$ stabilization (Formagini et al., 2013).

Microalgae are a generic term without taxonomic value, covering organisms of wellvaried morphology and cell structure: phylogenetically they are prokaryotic or eukaryotic, unicellular, colonial or filamentous and usually microscopic. Among the photosynthetic organisms, microalgae are the most efficient in the absorption of $\mathrm{CO}_{2}$, since they require large quantities of $\mathrm{CO}_{2}$ as carbon source (Chisti, 2007).

Fatty acids and lipids are present in the composition of cell membranes as well as the storage compounds, metabolites and sources of energy (Banerjee et al., 2002). As the $\mathrm{CO}_{2}$ resulting from industrial processes can be used by microalgae cells to carry out the photosynthesis, it is interesting that microalgae culture is fertilizer with $\mathrm{CO}_{2}$, instead of it be released into the atmosphere. Microalgae require large quantities of $\mathrm{CO}_{2}$ as nutrient; with potential to function as carbon sink. The consumption of microalgae for food is a tradition which dates back to very old ages, where native peoples from Asia consumed some species of the genus Nostoc, and other people such as the Aztecs in Mexico and the Kanembous in Africa, consumed algae of the genus Spirulina (Cenciani et al., 2011).

This study considered the prokaryotic microalgae - blue green algae (Cyanophyceae) and the eukaryotic microalgae - green algae (Chlorophyta) can be found in seawater, brackish, freshwater and in the soil. Under the name of microalgae some species that have chlorophyll a, have a photosynthetic process similar to the higher plants and other pigments (Pérez, 2007; Patil et al., 2008).

Cenciani et al. (2011) reported that, the biochemical composition of microalgae is not only determined by the nature of each species or strain, but also is strongly influenced by 
factors such as light intensity, temperature, $\mathrm{pH}$, nutrients and agitation of the culture medium.

According to Becker (2004) microalgae exhibit high levels of proteins and lipids, reaching values of $71 \%$ and $22 \%$ (dry mass) respectively, depend on the algal species. The interaction of these factors can contribute significantly to optimize the growth of microalgae. Algal cultivation is gradually increasing worldwide (Sheehan et al., 1998; Dayananda et al., 2005; Spolaore et al., 2006).

The cultivation of microalgae provides a number of other economic advantages such as relatively low costs for harvesting and transportation, lower cost of water use areas in fertile soils as support for the system of cultivation, high efficiency of $\mathrm{CO}_{2}$ photosynthetic fixation by area and the ability to grow in saline simple media (Danielo, 2005; Andrade and Costa, 2007).

Maynard et al. (1999) and Andrade and Costa (2007) mentioned that microorganism are able to rapidly consume nutrients and organic or inorganic carbon, for which they have been studied for the degradation of pollutants such as phenols, aromatic compounds and recalcitrant biopolymers as melanoidins. This process is known as phytoremediation and have applications such as: (a) removal of nutrients in sewage and effluent rich in organic matter, (b) industrial wastewater treatment with trace metals and acids, (c) $\mathrm{CO}_{2}$ sequestration, (d) processing and degradation of xenobiotic and (e) detection of toxic compounds using algae-based sensors (Olguin et al., 2001; Olguin, 2003 and Singh and Patel, 2012; Andres et al., 2014).

The cultivation of microalgae is used for the production of valuable chemical compounds, including natural pigments, biofuels and dietary supplements. In spite of the progresses in cultivation techniques and the design of high efficiency photobioreactors, biomass productivity is still low and more research is needed to develop large-scale processes for the production of these microorganisms (Andrade and Costa, 2007).

Spirulina is a cyanobacterium most often considered in microalgae cultivation due to its high productivity, it is often considered for biomass production due to its high cell growth rate, ease of harvesting and potential market as a human food supplement and animal feed. S. platensis is rich in a diverse range of active compounds such as protein, minerals, vitamins, pigments (phycocyanin and carotene) and polyunsaturated fatty acids (gamma-linoleic acid) (Cohen et al., 1987).

Nutritional studies have shown that Spirulina platensis contains essential amino acids in the proportions recommended by the WHO/FAO, except for methionine (Becker, 2007). Several reports related to the growth of Spirulina platensis in mineral media have been published (Converti et al., 2006; Colla et al., 2007; Bezerra et al., 2011). Although it has been shown that $S$. platensis can metabolize both inorganic and organic carbon substrates (i.e., glucose, acetate) for mixotrophic growth (Chojnacka and Noworyta, 2004; Lodi et al., 
2005) and ammonium and urea as alternative nitrogen sources (Matsudo et al., 2009; Sassano et al., 2010).

The cultivation of Spirulina platensis in complex media using industrial wastes, besides animal and livestock wastes (swine, cattle, poultry), is scarce (Markou and Georgakakis, 2011; Pittman et al., 2011; Coca et al., 2014) and polyunsaturated fatty acids (Cohen et al., 1987). However, the cultivation of Spirulina in complex media using industrial wastes is scanty (Olguin et al., 2001).

Chlorella vulgaris has been proposed for the treatment of effluents due to its easy adaptability and rapid growth (Travieso et al., 2008). In the treatment of vinasse, Valderrama et al (2002) used cultures of Chlorella vulgaris supplemented for 4 days for other 6 days macrophytes achieving a reduction in color of 52\%. Travieso et al. (1999) and (2008) used culture of Chlorella vulgaris after an anaerobic pretreatment stillage, resulting an excellent culture medium for the growth of algae. However to date there are no reported work in which local stillage are evaluated as a culture medium for the growth of microalgae, or the quality of the biomass produced from these with intent to obtain value added products (Andres et al., 2014).

However, there are very few published reports focusing on the cultivation of microalgae using vinasse, there are no reports on Spirulina platensis production (Montenegro-Ferraz et al., 1986; Travieso et al., 1999; Valderrama et al., 2002).

The productivity and composition of cell biomass may differ according to species and culture conditions (Radmann et al., 2007), it is necessary to provide an understanding of the growth of its cultures supplemented with beet vinasse. The work of Coca et al. (2014) is to evaluate the production of Chlorella Vulgaris, Spirulina Platensis and Nostoc commune in mineral media supplemented with sugarcane vinasse, as well as to analyze the influence of vinasse addition on biomass concentration and protein productivity in a vertical airlift photobioreactors.

Biotechnology researches indicate that the main application of microalgae biomass is for production of food supplements, but the cultivation has been restricted to few species belonging to the genera Chlorella, Dunaliella, Scenedesmus (Chlorophyta) and Spirulina (Cyanophyceae) (Becker, 2004).

The use and advantages of various genera of microalgae for production of biodiesel have been widely discussed in literature (Sheehan et al., 1998; Sawayama et al., 1999; Danielo, 2005; Metzger and Largeau, 2005; Chisti, 2007; Ranga Rao et al., 2007; Wagner, 2007; Chisti, 2008; Cenciani et al., 2011).

Montenegro et al. (2009) and Gallego-Blanco et al., (2012) reported that, the exchangeable bases $\mathrm{Ca}$ and $\mathrm{Mg}$ showed no statistically significant differences between treatments. The authors found no changes in the content of these bases after application of 
vinasse to the soil. However, Quintero (2008) takes the opposite view in stating that the consecutive application of vinasse for 20 years slightly increased contents of $\mathrm{Ca}$ and $\mathrm{Mg}$ in the soil.

Armengol et al. (2003) discussed that, vinasse dilutions increased the content of calcium and other cations, as well as base exchange capacity. Results proved that treatments using vinasse with water improved soil inter cationic balance; also, base-exchange capacity and yields increased and the useful life period of the strain lengthened. Increases achieved by vinasse dilutions denote its marked effect as calcium source for these soils.

Quintero (2008); Gemtos et al. (1999) and Montenegro et al. (2009) reported that the $K$ content increased markedly after adding vinasse to the soil. Jiang et al. (2012) found that the $\mathrm{K}$ content in soils treated with vinasse was significantly higher than in soils without any treatment. The authors stated that high concentrations of $K$ in the vinasse make this a useful byproduct as a fertilizer in all soil types. It is possible that in this study changes in soil $\mathrm{K}$ content were not able to manifest due to the short time of evaluation.

The content of phosphorus in the soil before and after application of vinasse showed no statistically significant changes. The values of this element always remained classified as very high. The same trend in this element was reported by Jiang et al. (2012), the authors found no significant changes between soils fertilized with vinasse and unfertilized soils (GallegoBlanco et al., 2012).

In Egypt, the sugar and integrated industries company produce more than $2.000 \mathrm{~m}^{3} / \mathrm{d}$ of byproduct. It represents residues from molasses fermentation process (Arafat and Yassen, 2002).

\section{Material and Methods:}

Physico-chemical parameters:

1) Hydrogen - ion concentration $(\mathrm{pH})$ : $\mathrm{pH}$ was measured in situ by a $\mathrm{pH}$ meter.

2) Electric conductivity (EC): By conductivity YSI model 33 S.C.T. meter.

3) Determination of Ammonia $\left(\mathrm{NH}_{3}\right)$ : Ammonia was determined calorimetrically by using UV/Visible spectrophotometer at wave length $400 \mathrm{~nm}$ (ASTM, 2007).

4) Determination of Nitrate $\left(\mathrm{NO}_{3}{ }^{-}\right)$: Nitrate was determined calorimetrically by using UV/Visible spectrophotometer at wave length $430 \mathrm{~nm}$ (ASTM, 2007).

5) Total phosphorus: Phosphorus was determined calorimetrically by phospho-molybdate method using UV/Visible spectrophotometer at wave length 700 or $880 \mathrm{~nm}$ (ASTM, 2007).

6) Calcium and Magnesium: Calcium $\left(\mathrm{Ca}^{+2}\right)$ and magnesium $\left(\mathrm{Mg}^{+2}\right)$ cations were determined using atomic absorption spectrophotometer method (Jackson, 1973). 
7) Sodium and Potassium: Sodium $\left(\mathrm{Na}^{+}\right)$and potassium $\left(\mathrm{K}^{+}\right)$ions were determined calorimetrically by means of flame-photometer (ASTM, 2007).

Microalgae and digested vinasse:

One axenic culture of green alga (Chlorella vulgaris) and two pure strains of blue green algae (Spirulina platensis and Nostoc commune) were obtained from the Agricultural Microbiology Department, Soils, Water and Environment Institute, Agricultural Research Center, Egypt.

Vinasse was diluted with sterile distilled water in ratio as follow: $0.1 \%, 0.2 \%, 0.3 \%$, $0.01 \%, 0.02 \%$ and $0.03 \%$ (with adapted $\mathrm{pH}$ to 7 ). Bold basal media (Bischaffi and Bold, 1963) used as control with green alga and Zarrouk media (Zarrouk, 1966) as control with blue green algae. Digested vinasse used in this study contained (after analysis) $2750 \mathrm{mg} / \mathrm{l}$ ammonia $\left(\mathrm{NH}_{3}\right), 3060 \mathrm{mg} / \mathrm{l}$ nitrate $\left(\mathrm{NO}_{3}\right), 1072 \mathrm{mg} / \mathrm{l}$ Phosphate $\left(\mathrm{PO}_{4}\right), 49400$ umhos/cm Electron Conductivity (EC), 5166 mg/l Calcium (Ca), 6381 mg/l Magnesium (Mg), 4000 mg/l Sodium (Na), $27000 \mathrm{mg} / \mathrm{l}$ Potassium (K).

\section{Experimental procedure:}

The experiment was carried out in $500 \mathrm{ml}$ Erlenmeyer flasks containing $250 \mathrm{ml}$ sample. Each concentration was inoculated by $5 \mathrm{ml}$ of Chlorella vulgaris, Spirulina platensis or Nostoc commune. The test flasks and control were incubated at $28-30{ }^{\circ} \mathrm{C}$ under light of 4000 lux intensity from fluorescent tubes at light cycle of 14 hour light followed by 10 hour darkness.

Experimental and control culture were in duplicate and divided into 2 groups. Incubation for the first period ( 21 days for all species) and the second period ( 35 days for all species).

\section{Analytical procedure:}

Biomass concentration was determined by measuring:

a) Cell number counting: Algal cell counts were made microscopically using a haemocytometer for Chlorella vulgaris (Guillard, 1978) and by Sedguick-Rafter slide for Spirulina platensis and Nostoc commune (APHA, 1995).

b) Chlorophyll (a): chlorophyll-a content was determined for each test organisms with extraction by $90 \%$ acetone (APHA, 1995).

c) Protein content: protein content was measured spectro- photometrically using the Folinphenol reagent according to Lowry et al. (1951).

d) Total carbohydrates: the spectrophotometric method described by Dubois et al. (1956) was used to determine carbohydrates. 
e) Dry weight: after the two periods of growth (21 and 35 days), all the algal media were filtered and dried in the oven.

\section{Results and Discussion}

\section{Physico-chemical parameters of vinasse:}

The present investigation showed that digested vinasse contained $2750 \mathrm{mg} / \mathrm{L}$ ammonia $\left(\mathrm{NH}_{3}\right), 3060 \mathrm{mg} / \mathrm{L}$ nitrate $\left(\mathrm{NO}_{3}\right), 1072 \mathrm{mg} / \mathrm{L}$ phosphate $\left(\mathrm{PO}_{4}\right), 5166 \mathrm{mg} / \mathrm{L}$ Calcium (Ca), 6381 mg/L Magnesium (Mg), 4000 mg/L Sodium (Na), 27000 mg/L Potassium (K) and 49400 umhos/cm Electron Conductivity (EC).

\section{Microalgae and digested vinasse:}

\section{1- Number of algal species :}

Table 1 and Figure 1 show the number of individuals of the three chosen algae (Chlorella vulgaris, Spirulina platensis and Nostoc commune) grown on various concentrations of vinasse ( $0.01 \%, 0.02 \%, 0.03 \%, 0.1 \%, 0.2 \%$ and $0.3 \%$ ) for 21 and 35 days .

\section{Chlorella vulgaris:}

Chlorella vulgaris showed a high rate of growth during the second period (35 days) of growth more than the first one (21 days). The best concentration for the growth of Chlorella vulgaris was $0.3 \%\left(368 \times 10^{6}\right.$ ) at the second period (35 days). While $0.01 \%$ was the least concentration for its growth (8.6 and $24 \times 10^{6} / \mathrm{L}$ during periods one and two, respectively). The control culture (BBM media) recorded the values of 48 and $80 \times 10^{6} / \mathrm{L}$ as a minimum and a maximum values, respectively.

\section{Spirulina platensis:}

Spirulina platensis showed a high rate of growth during the second period ( 35 days) of growth more than the first one (21 days). The best growth for it was during the second period of growth (35 days) at concentration media of $0.02 \%\left(200 \times 10^{6} / L\right)$, while $0.2 \%$ was the least concentration media for its growth $\left(9 \times 10^{6} / \mathrm{L}\right)$ during the first period ( 21 days). The control culture (Zarrouk media) recorded the values of 2 and 8 individual $\times 10^{6} / L$ as a minimum and a maximum values, respectively. There was no growth of Spirulina platensis at $\mathbf{0 . 3 \%}$ concentration for the two periods of growth.

\section{Nostoc commune:}

Nostoc commune showed a high rate of growth during the second period ( 35 days) of growth more than the first one ( 21 days). The best concentration for the growth of it was $0.01 \%$ (1000 and 1400 individual x 10\% /L during periods 1 and 2, respectively. On the other hand, $\mathbf{0 . 3} \%$ was the least concentration for the growth of Nostoc commune ( $\mathbf{0}$ and $\mathbf{1}$ 
individual $\times 10^{6} / \mathrm{L}$ ) during periods 1 and 2 , respectively. The control culture recorded the values of 312 and 640 individual $\times 10^{6} / \mathrm{L}$ as a minimum and a maximum values respectively.

Table 1: Number of the algal species per liter which grow on different concentrations for vinasse after 21 and 35 days (individuals $\times 10^{6}$ ).

\begin{tabular}{|c|c|c|c|c|}
\hline & & Chlorella vulgaris & Spirulina platensis & $\begin{array}{l}\text { Nostoc } \\
\text { commune. }\end{array}$ \\
\hline & control & 48 & 2 & 312 \\
\hline & $0.01 \%$ & 8.6 & 74 & 1000 \\
\hline & $0.02 \%$ & 12 & 132 & 647 \\
\hline 21 days & $0.03 \%$ & 18 & 52 & 581 \\
\hline & $0.10 \%$ & 90 & 18 & 3 \\
\hline & $0.20 \%$ & 143 & 9 & 1 \\
\hline & $0.30 \%$ & 179 & 0 & 0 \\
\hline LSD at 0. & & 8.25 & 6.42 & 10.78 \\
\hline & control & 80 & 8 & 640 \\
\hline & $0.01 \%$ & 24 & 180 & 1400 \\
\hline & $0.02 \%$ & 36 & 200 & 880 \\
\hline 35 days & $0.03 \%$ & 52 & 96 & 360 \\
\hline & $0.10 \%$ & 120 & 40 & 8 \\
\hline & $0.20 \%$ & 320 & 20 & 3 \\
\hline & $0.30 \%$ & 368 & 0 & 1 \\
\hline LSD at 0. & & 5.62 & 16.25 & 6.43 \\
\hline
\end{tabular}

LSD (least significant difference) 


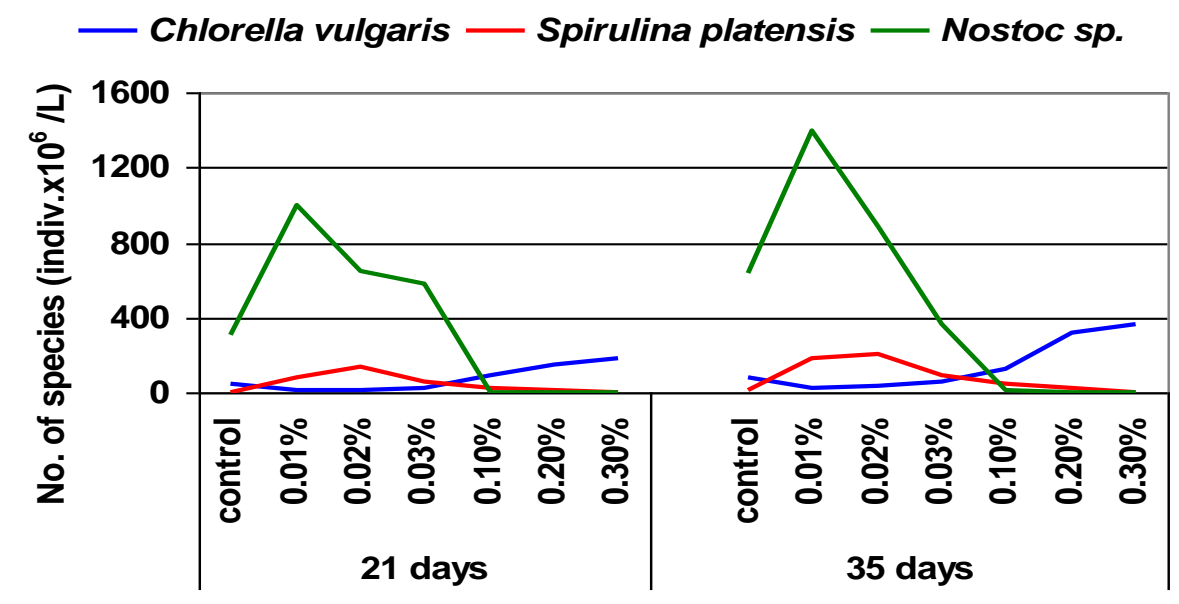

Fig 1: Number of the algal species which grow on different concentrations for vinasse after 21 and 35 days (individuals $\times 10^{6}$ ).

2-Chlorophyll-a:

Data in Table $\mathbf{2}$ and Figure $\mathbf{2}$ show the effect of various concentrations of vinasse on chlorophyll-a content by the tested algae (Chlorella vulgaris, Spirulina platensis and Nostoc commune) grown on various concentrations of vinasse $(0.01 \%, 0.02 \%, 0.03 \%, 0.1 \%, 0.2$ $\%$ and $0.3 \%$ ) after 21 and 35 days.

\section{Chlorella vulgaris:}

Chlorella vulgaris recorded the maximum values of chlorophyll a $(29.90$ and $\mathbf{6 2 . 2 0}$ $\mathrm{mg} / \mathrm{L}$ ) at the concentration of $\mathbf{0 . 3 \%}$ during the periods 1 and 2, respectively, while the minimum value was recorded at the concentration of $0.01 \%(0.21$ and $0.94 \mathrm{mg} / \mathrm{L})$ during the periods 1 and 2, respectively. The control culture recorded the values of 4.17 and 10.41 $\mathrm{mg} / \mathrm{L}$ as a minimum and a maximum values respectively.

\section{Spirulina platensis:}

Spirulina platensis recorded the maximum values of chlorophyll a (12 and $\mathbf{2 0 . 2} \mathrm{mg} / \mathrm{L}$ ) at the concentration of $\mathbf{0 . 0 2 \%}$ during periods 1 and 2 respectively, while the minimum values were recorded at the concentration of $\mathbf{0 . 2 \%}(0.37$ and $0.78 \mathrm{mg} / \mathrm{L})$ respectively during periods 1 and 2 . The control culture recorded the values of 0.01 and $0.24 \mathrm{mg} / \mathrm{L}$ as a minimum and a maximum values respectively.

\section{Nostoc commune:}

Nostoc commune recorded the maximum values of chlorophyll-a (81.2 and $\mathbf{1 0 2} \mathrm{mg} / \mathrm{L})$ at the concentration of $\mathbf{0 . 0 1 \%}$ during periods 1 and 2 respectively, while the minimum values of chlorophyll-a (0.02 and $\mathbf{0 . 0 1} \mathrm{mg} / \mathrm{L})$ were recorded at the concentration of $\mathbf{0 . 3 0 \%}$ during 
periods 1 and 2 respectively. The control culture recorded the values of $\mathbf{3 4 . 2 1}$ and $\mathbf{7 1 . 6 2}$ $\mathrm{mg} / \mathrm{L}$ as a minimum and a maximum values respectively.

Table 2: Effect of various concentrations of vinasse on Chlorophyll-a content ( $\mathrm{mg} / \mathrm{L}$ ) for different algal species after 21 and 35 days, respectively.

\begin{tabular}{|c|c|c|c|c|}
\hline & Chlorella vulgaris & Spirulina platensis & $\begin{array}{l}\text { Nostoc } \\
\text { commune }\end{array}$ \\
\hline \multirow{7}{*}{21 days } & control & 4.20 & 0.01 & 34.20 \\
\hline & $0.01 \%$ & 0.21 & 10.10 & 81.20 \\
\hline & $0.02 \%$ & 1.00 & 12.00 & 53.20 \\
\hline & $0.03 \%$ & 3.40 & 11.1 & 11.10 \\
\hline & $0.10 \%$ & 9.90 & 0.41 & 0.63 \\
\hline & $0.20 \%$ & 11.20 & 0.37 & 0.02 \\
\hline & $0.30 \%$ & 29.90 & 0 & 0 \\
\hline \multicolumn{2}{|c|}{ LSD at 0.05} & 1.18 & 1.69. & 10.58 \\
\hline \multirow{7}{*}{35 days } & control & 10.40 & 0.24 & 71.60 \\
\hline & $0.01 \%$ & 0.94 & 17.90 & 102.00 \\
\hline & $0.02 \%$ & 2.38 & 20.20 & 31.10 \\
\hline & $0.03 \%$ & 2.47 & 10.00 & 20.20 \\
\hline & $0.10 \%$ & 13.5 & 3.00 & 2.10 \\
\hline & $0.20 \%$ & 60.60 & 0.78 & 0.12 \\
\hline & $0.30 \%$ & 62.20 & 0 & 0.01 \\
\hline \multicolumn{2}{|c|}{ LSD at 0.05} & 7.62 & 6.40 & 7.28 \\
\hline
\end{tabular}

LSD (least significant difference) 


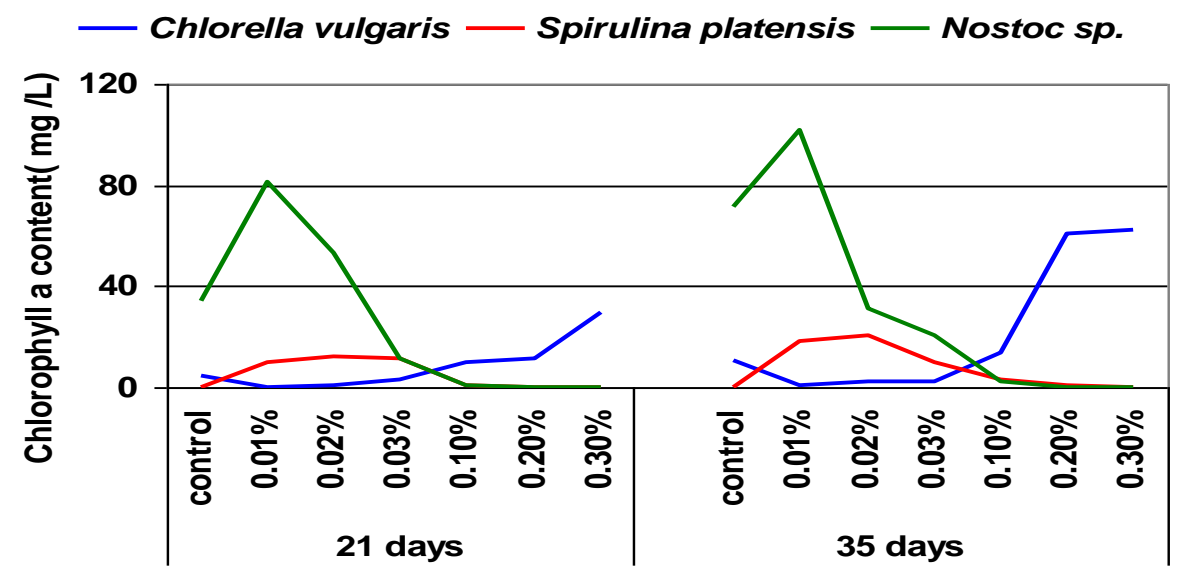

Fig 2: Effect of various concentrations of vinasse on Chlorophyll-a content $(\mathrm{mg} / \mathrm{L})$ for different algal species after 21 and 35 days, respectively.

\section{3- Protein:}

Data in Table 3 and Figure 3 show the effect of various concentrations of vinasse on protein contents by the tested algae (Chlorella vulgaris, Spirulina platensis and Nostoc commune) grown on various concentrations of vinasse $(0.01 \%, 0.02 \%, 0.03 \%, 0.1 \%, 0.2$ $\%$ and $0.3 \%$ ) after 21 and 35 days.

\section{Chlorella vulgaris:}

Chlorella vulgaris recorded the maximum values of protein at the concentration of $\mathbf{0 . 3 \%}$ $(91.26$ and $103.49 \mathrm{mg} / \mathrm{L})$ during the periods 1 and 2 respectively, while the minimum value of protein was recorded at the concentration of $\mathbf{0 . 0 1 \%}(\mathbf{3 4 . 0 0} \mathrm{mg} / \mathrm{L})$ during the two periods. The control culture recorded the values of 72.02 and $73.41 \mathrm{mg} / \mathrm{L}$ as a minimum and a maximum values respectively.

\section{Spirulina platensis:}

Spirulina platensis recorded the maximum values of protein at the concentration of $\mathbf{0 . 0 2 \%}$ (118.5 and $\mathbf{1 5 4 . 7} \mathrm{mg} / \mathrm{L}$ ) during periods 1 and 2 respectively, while the minimum value of protein was recorded at the concentration of $0.3 \%$ (zero $\mathrm{mg} / \mathrm{L}$ ) during periods 1 and 2 . The control culture recorded the values of 95.03 and $99.21 \mathrm{mg} / \mathrm{L}$ as a minimum and a maximum values respectively.

\section{Nostoc commune:}

Nostoc commune recorded the maximum values of protein at the concentration of $\mathbf{0 . 0 1 \%}$ (87.51 and $\mathbf{1 0 6 . 2} \mathrm{mg} / \mathrm{L}$ ) during periods 1 and 2 respectively, while the minimum value of protein was recorded at the concentration of $0.3 \%$ (zero $\mathrm{mg} / \mathrm{L})$ during the two periods. The control culture recorded the values of $\mathbf{3 0 . 4 6}$ and $\mathbf{7 0 . 2 3} \mathrm{mg} / \mathrm{L}$ as a minimum and a maximum values respectively. 
Table 3: Effect of various concentrations of vinasse on protein contents $(\mathrm{mg} / \mathrm{L})$ for different algal species after 21 and 35 days

\begin{tabular}{|c|c|c|c|c|}
\hline & Chlorella vulgaris & Spirulina platensis & $\begin{array}{l}\text { Nostoc } \\
\text { commune }\end{array}$ \\
\hline \multirow{7}{*}{21 days } & control & 72.02 & 95.03 & 30.46 \\
\hline & $0.01 \%$ & 34.00 & 88.58 & 87.51 \\
\hline & $0.02 \%$ & 72.44 & 118.5 & 59.01 \\
\hline & $0.03 \%$ & 72.79 & 99.98 & 31.94 \\
\hline & $0.10 \%$ & 80.15 & 89.73 & 10.35 \\
\hline & $0.20 \%$ & 89.68 & 89.39 & 9.24 \\
\hline & $0.30 \%$ & 91.26 & 0 & 0 \\
\hline \multicolumn{2}{|c|}{ LSD at 0.05} & 6.28 & 8.63 & 15.33 \\
\hline \multirow{7}{*}{35 days } & control & 73.41 & 99.21 & 70.23 \\
\hline & $0.01 \%$ & 34.00 & 90.68 & 106.20 \\
\hline & $0.02 \%$ & 72.96 & 154.70 & 83.11 \\
\hline & $0.03 \%$ & 75.87 & 103.70 & 54.43 \\
\hline & $0.10 \%$ & 85.62 & 96.70 & 14.72 \\
\hline & $0.20 \%$ & 97.36 & 93.72 & 8.39 \\
\hline & $0.30 \%$ & 103.5 & 0 & 0 \\
\hline \multicolumn{2}{|c|}{ LSD at 0.05} & 8.47 & 9.06 & 11.28 \\
\hline
\end{tabular}

LSD (least significant difference) 


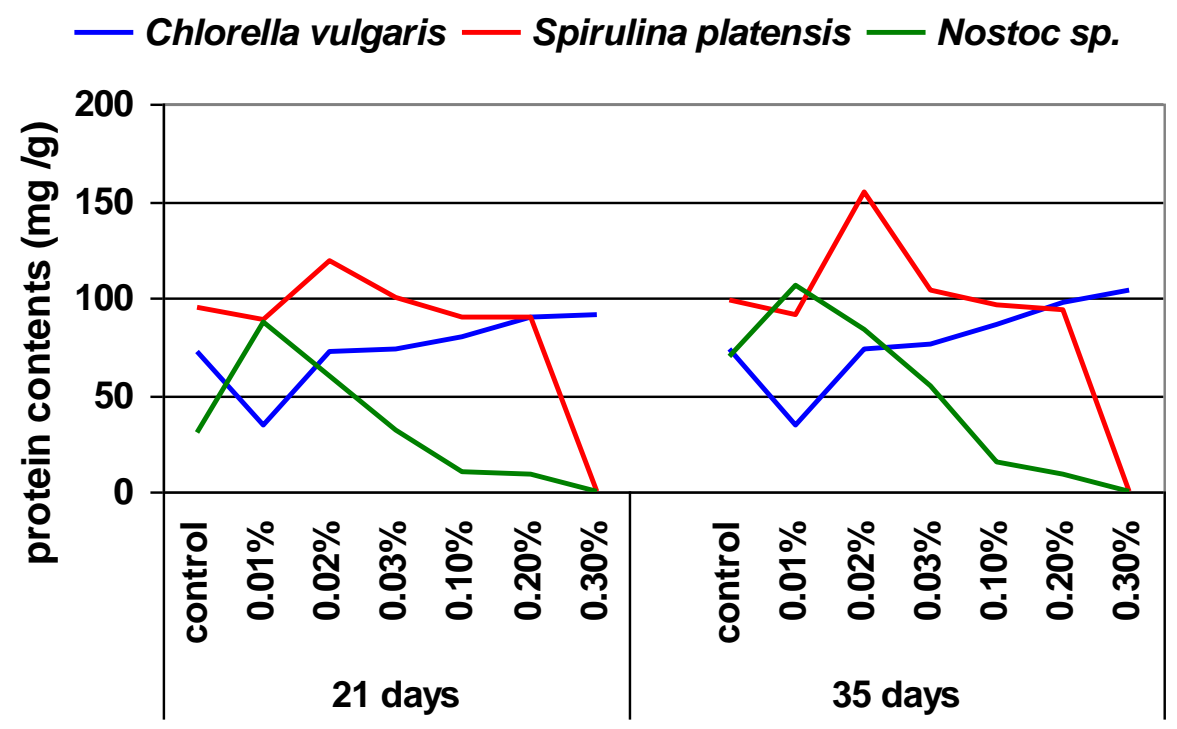

Fig. 3: Effect of various concentrations of vinasse on protein contents $(\mathrm{mg} / \mathrm{l})$ for different algal species after 21 and 35 days.

\section{4- Carbohydrates:}

Data in Table 4 and Figure 4 show the effect of various concentrations of vinasse on carbohydrate contents by the tested algae (Chlorella vulgaris, Spirulina platensis and Nostoc commune) grown on various concentrations of vinasse $(0.01 \%, 0.02 \%, 0.03 \%, 0.1 \%, 0.2$ $\%$ and $\mathbf{0 . 3} \%$ ) after 21 and 35 days.

\section{Chlorella vulgaris :}

Chlorella vulgaris recorded the maximum values of carbohydrates at the concentration

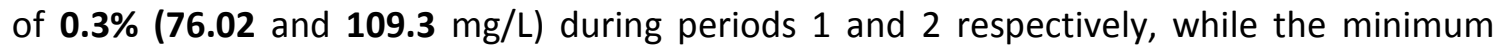
values of carbohydrates were recorded at the concentration of $\mathbf{0 . 0 1 \%}$ (38.58 and $\mathbf{4 0 . 6 8}$ $\mathrm{mg} / \mathrm{L}$ ) during the period 1 and 2 respectively. The control culture recorded the values of $\mathbf{4 5 . 0 3}$ and $\mathbf{4 9 . 2 1} \mathrm{mg} / \mathrm{L}$ as a minimum and a maximum values respectively.

\section{Spirulina platensis:}

Spirulina platensis recorded the maximum value of carbohydrates at the concentration of $0.01 \%$ ( 57.26 and $69.49 \mathrm{mg} / \mathrm{L}$ ) during the periods 1 and 2 respectively, while the minimum value of carbohydrates was recorded at the concentration of $\mathbf{0 . 3 \%}$ (zero $\mathrm{mg} / \mathrm{L}$ during the two periods). The control culture recorded the values of $\mathbf{3 8 . 0 2}$ and $\mathbf{3 9 . 4 1} \mathrm{mg} / \mathrm{L}$ as a minimum and a maximum values respectively. 


\section{Nostoc commune:}

Nostoc commune recorded the maximum values of carbohydrates at the concentration of $\mathbf{0 . 0 1 \%}$ (134.51 and $\mathbf{1 5 3 . 2} \mathrm{mg} / \mathrm{L}$ ) during the periods 1 and 2 respectively, while the minimum value of carbohydrates was recorded at the concentration of $0.3 \%$ (zero $\mathrm{mg} / \mathrm{L}$ ) during the two periods. The control culture recorded the values of $\mathbf{7 7 . 4 6}$ and $\mathbf{1 1 7 . 2 3} \mathrm{mg} / \mathrm{L}$ as a minimum and a maximum values respectively.

Table 4: Effect of various concentrations of vinasse on carbohydrates content $(\mathrm{mg} / \mathrm{L})$ for different algal species after 21 and 35 days.

\begin{tabular}{|c|c|c|c|c|}
\hline & Chlorella vulgaris & Spirulina platensis & $\begin{array}{l}\text { Nostoc } \\
\text { commune. }\end{array}$ \\
\hline \multirow{7}{*}{21 days } & control & 45.03 & 38.02 & 77.46 \\
\hline & $0.01 \%$ & 38.58 & 57.26 & 134.51 \\
\hline & $0.02 \%$ & 39.39 & 55.68 & 106.00 \\
\hline & $0.03 \%$ & 39.73 & 46.15 & 78.94 \\
\hline & $0.10 \%$ & 49.98 & 38.79 & 38.03 \\
\hline & $0.20 \%$ & 68.45 & 38.44 & 38.01 \\
\hline & $0.30 \%$ & 76.02 & 0 & 0 \\
\hline \multicolumn{2}{|c|}{ LSD at 0.05} & 6.15 & 5.82 & 13.26 \\
\hline \multirow{7}{*}{35 days } & control & 49.21 & 39.41 & 117.23 \\
\hline & $0.01 \%$ & 40.68 & 69.49 & 153.20 \\
\hline & $0.02 \%$ & 43.72 & 63.36 & 130.10 \\
\hline & $0.03 \%$ & 46.70 & 51.62 & 101.40 \\
\hline & $0.10 \%$ & 53.67 & 41.87 & 38.38 \\
\hline & $0.20 \%$ & 104.70 & 38.96 & 38.15 \\
\hline & $0.30 \%$ & 109.30 & 0 & 0 \\
\hline \multicolumn{2}{|c|}{ LSD at 0.05} & 5.04 & 6.11 & 10.28 \\
\hline
\end{tabular}

LSD (least significant difference) 


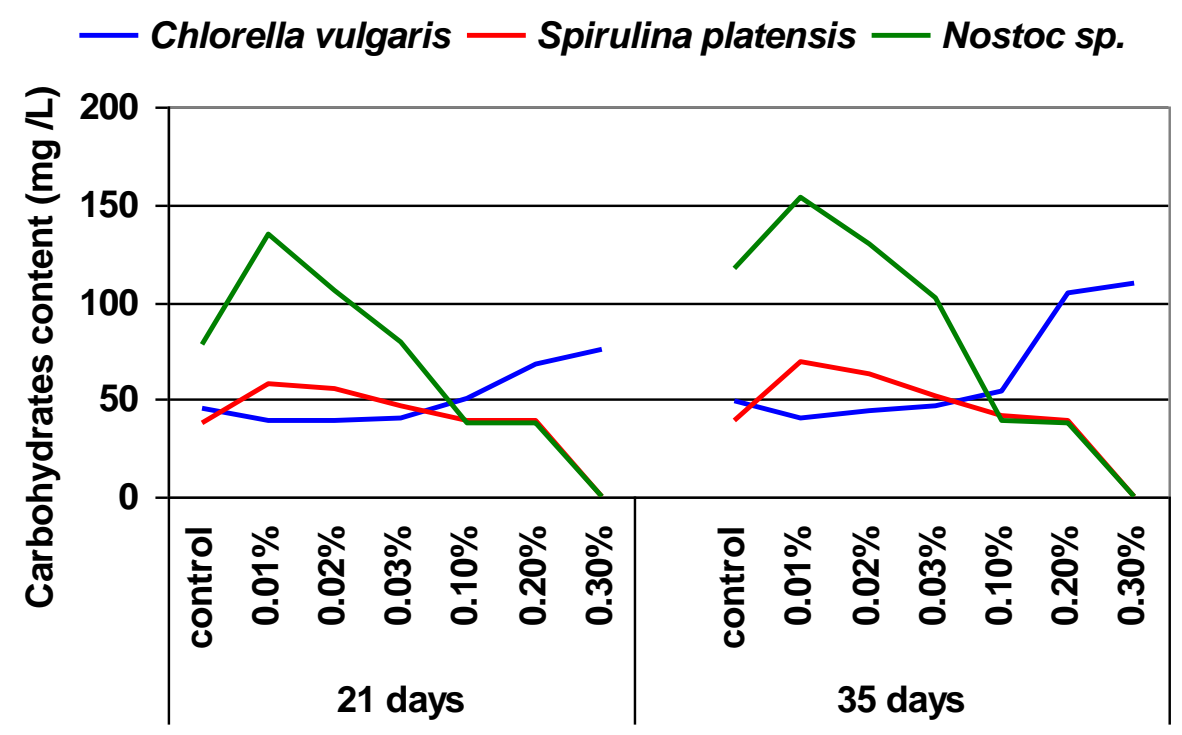

Fig 4: Effect of various concentrations of vinasse on carbohydrates content $(\mathrm{mg} / \mathrm{L})$ for different algal species after 21 and 35 days.

\section{5- Dry weight:}

Data in Table $\mathbf{5}$ and Figure $\mathbf{5}$ show the effect of various concentrations of vinasse on dry weight of the tested algae (Chlorella vulgaris, Spirulina platensis and Nostoc commune) grown on various concentrations of vinasse $(0.01 \%, 0.02 \%, 0.03 \%, 0.1 \%, 0.2 \%$ and 0.3 \%) after 21 and 35 days.

\section{Chlorella vulgaris:}

Chlorella vulgaris recorded the maximum values of dry weight at the concentration of $\mathbf{0 . 3 \%}(\mathbf{1 4 . 4 0}$ and $\mathbf{2 8 . 4 5} \mathrm{mg} / \mathrm{L}$ ) during the periods 1 and 2 respectively, while the minimum values of dry weight were recorded at the concentration of $\mathbf{0 . 0 1 \%}(0.95$ and $2 \mathrm{mg} / \mathrm{L})$ during periods 1 and 2 respectively. The control culture recorded the values of 5.30 and $\mathbf{7 . 1 2} \mathrm{mg} / \mathrm{L}$ as a minimum and a maximum values respectively.

\section{Spirulina platensis:}

Spirulina platensis recorded the maximum values of dry weight at the concentration of $\mathbf{0 . 0 2 \%}(\mathbf{8 . 5}$ and $\mathbf{1 6 . 5} \mathrm{mg} / \mathrm{L})$ during the periods 1 and 2 respectively, while the minimum values of dry weight was recorded at the concentration of $\mathbf{0 . 3 \%}$ (zero $\mathrm{mg} / \mathrm{L}$ ) during the two periods. The control culture recorded the values of 0.1 and $0.9 \mathrm{mg} / \mathrm{L}$ as a minimum and a maximum values respectively. 


\section{Nostoc commune:}

Nostoc commune recorded the maximum values of dry weight at the concentration of $\mathbf{0 . 0 1 \%}$ (112.0 and $\mathbf{1 5 3 . 0} \mathrm{mg} / \mathrm{L}$ ) during the periods 1 and 2 respectively, while the minimum value of dry weight was recorded at the $0.3 \%$ concentration (zero $\mathrm{mg} / \mathrm{L}$ during the two periods 1 and 2). The control culture recorded the values of $\mathbf{2 5 . 5}$ and $\mathbf{5 7 . 0} \mathrm{mg} / \mathrm{L}$ as a minimum and a maximum values respectively.

Table 5: Effect of various concentrations of vinasse on dry weight content $(\mathrm{mg} / \mathrm{L})$ for different algal species after 21 and 35 days

\begin{tabular}{|c|c|c|c|c|}
\hline & & Chlorella vulgaris & Spirulina platensis & $\begin{array}{l}\text { Nostoc } \\
\text { commune. }\end{array}$ \\
\hline & control & 5.30 & 0.10 & 25.50 \\
\hline & $0.01 \%$ & 0.95 & 6.00 & 112.00 \\
\hline & $0.02 \%$ & 1.14 & 8.50 & 81.00 \\
\hline 21 days & $0.03 \%$ & 1.70 & 1.30 & 28.70 \\
\hline & $0.10 \%$ & 6.45 & 1.60 & 0.39 \\
\hline & $0.20 \%$ & 10.50 & 0.23 & 0.18 \\
\hline & $0.30 \%$ & 14.40 & 0 & 0 \\
\hline LSD at 0. & & 2.56 & 2.14 & 8.62 \\
\hline & control & 7.12 & 0.90 & 57.00 \\
\hline & $0.01 \%$ & 2.00 & 10.00 & 153.00 \\
\hline & $0.02 \%$ & 4.20 & 16.50 & 99.50 \\
\hline 35 days & $0.03 \%$ & 5.80 & 4.90 & 42.00 \\
\hline & $0.10 \%$ & 9.70 & 1.98 & 1.67 \\
\hline & $0.20 \%$ & 21.50 & 0.98 & 0.40 \\
\hline & $0.30 \%$ & 28.45 & 0 & 0 \\
\hline LSD at 0. & & 1.48 & 3.68 & 8.96 \\
\hline
\end{tabular}

LSD (least significant difference) 


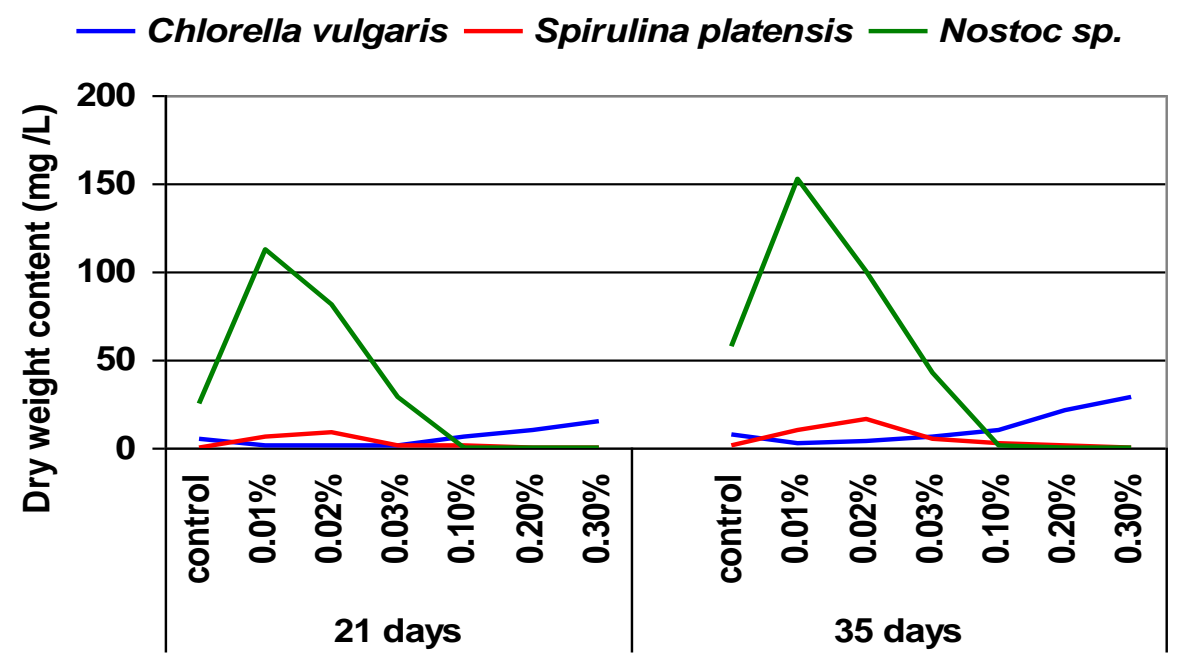

Fig. 5: Effect of various concentrations of vinasse on dry weight content $(\mathrm{mg} / \mathrm{L}$ ) for different algal species after 21 and 35 days.

In the present study the results showed that the lower concentrations of digested vinasse in the vinasse media, enhance the growth of Spirulina platensis and Nostoc commune grow (Table 1 and Figure 1), this in disagreement with Budiyono et al. (2013) in case of S. platensis and N. commune, while agreement in the case of Chlorella vulgaris, where the higher concentration of added digested vinasse lead to Chlorella vulgaris grow faster.

Also in the present study the control (Zarrouk medium), Spirulina platensis showed lower growth rate $\left(2 \times 10^{6} / \mathrm{L}\right)$ while at the highest concentration of vinasse $(0.3 \%)$ it showed no growth, while Nostoc commune showed high growth rate $\left(312 \times 10^{6} / L\right)$ in the same medium (Zarrouk medium). This in disagreement with Budiyono et al. (2013), who found that, the high growth rate was at $\mathbf{0 . 0} \%$ digested vinasse (without any addition of vinasse). In the control Bold Basal Medium (BBM) Chlorella vulgaris showed intermediate state of growth rate $\left(48 \times 10^{6} / L\right)$ between the lower and the higher concentrations of vinasse, These results may be due to the addition of high concentration of vinasse which caused dark color and turbidity, so the penetration of light into medium was small, so this phenomenon disrupted photosynthetic activity of Spirulina platensis and Nostoc commune. The results mentioned above were in agreement with Cheunbarn and Peerapornpisal (2010), Victor et al. (2010) and Hadiyanto and Hartanto (2012) who stated that Spirulina platensis could not thrive in medium which contain high organic substances that could affect dark color and turbidity.

Ogbonna and Tanaka (1998) stated that addition of organic carbon would reduce the production of photosynthetic pigments, so rate of photosynthesis was slowly, so the more digested vinasse was added into medium, the more slowly rate of photosynthesis went on in 
system. This result is in agreement with the present investigation for Spirulina platensis and Nostoc commune, while in disagreement with the same author in case of Chlorella vulgaris.

Budiyono et al. (2013) reported that microalgae growth could be hampered by the presence of phenol in medium and digested vinasse contain phenolic compounds. Also some authors reported that Chlorella sp., Spirulina obliquus and Spirulina maxima cannot be able to grow by using phenol as carbon source. Klekner and Kosaric (1992), Semple and Cain (1997) and Scragg (2006) added that Chlorella vulgaris also cannot be thrive in medium containing phenolic compounds. Leonard and Lindley (1999) reported that phenol in medium damaged the structures of membrane cell. In the present investigation Spirulina platensis and Nostoc commune may not be able to grow with high rate at high concentrations of digested vinasse media because the same reason which illustrated by the above authors. While Chlorella vulgaris showed an opposite result which may be due to the different structure of the cell wall for green algae which gives it more tolerance.

In Spirulina cultivation $\mathrm{pH}$ is one of the most important factors and should be above 9.5 in order to avoid contamination by microalgae (Richmond and Grobbelaar, 1986; Belay, 1997 and Andrade and Costa, 2007). The increasing in $\mathrm{pH}$ was related with photosynthetic activity, where the higher the rate of photosynthetic activity, the higher the $\mathrm{pH}$ medium (Andrade and Costa, 2007). $\mathrm{pH}$ is the master parameter that controls all aquatic chemical and biological processes. Changes in $\mathrm{pH}$ values beyond the optimum range may affect microbial physiology (Abdo et al., 2010). Positive correlation was observed between phytoplankton and $\mathrm{pH}$ and alkalinity. In the present investigation the digested vinasse recorded $\mathrm{pH} 3$. But to get best growth for algae the $\mathrm{pH}$ for vinasse was adjusted at the favorable pH 9.5-10. This result in agreement with Richmond and Grobbelaar (1986); Belay (1997) and Andrade and Costa (2007).

Hase et al. (2000) and Andrade and Costa (2007) reported that there was a tendency for the $\mathrm{pH}$ to increase where light was highest. Hase et al. (2000) also reported an increase of $\mathrm{pH}$ in Chlorella vulgaris culture during the light phase when photosynthesis was occurring and a decrease in $\mathrm{pH}$ during the dark period when photosynthesis ceased and only heterotrophic growth occurred.

Membrane cell of Spirulina platensis broke (lysis), so organic materials in cell were dissolved into medium. This phenomenon might cause decreasing in $\mathrm{pH}$ medium (Fogg and Thake, 1987). In the present study the growth rate of Spirulina platensis decreased and $\mathrm{pH}$ also decreased at the concentration of vinasse media $0.1 \%, 0.2 \%, 0.3 \%$ and the control medium (BBM). The same may be also occurred with Nostoc commune at the same concentrations of vinasse media.

Budiyono et al. (2013) reported that the more concentration of digested vinasse were added, the more amount of bacteria was contained in medium, at beginning of cultivation oxidation bacteria in medium converted organic compounds of wastewater into $\mathrm{CO}_{2}$ via 
respiration. $\mathrm{CO}_{2}$ formed reacted with water to form carbonate, so medium to be acidic. Then, carbonate was used by S. platensis for photosynthetic process and released $\mathrm{OH}^{-}$, so $\mathrm{pH}$ medium gradually increased. In the present study the more concentration of digested vinasse were added the faster Chlorella vulgaris grow and the slower Spirulina platensis and Nostoc commune grow due to the increasing of $\mathrm{pH}$ which in agreement with Budiyono et al. (2013) in case of Chlorella vulgaris and in disagreement with them in case of Spirulina platensia and Nostoc commune.

Production of biomass in all concentrations during the first period ( 21 days) declined. This declined was called death phase because a lot of algae cells were death. This phase was occurred due to the age old culture and the limitation of light and energy supply (Budiyono et al., 2013). This is opposite to the results obtained in the present study which recorded more production of biomass for the three cultivated microalgae (Chlorella vulgaris, Spirulina platensis and Nostoc commune) during the second period of cultivation (35 days) which was the longest time of cultivation (Table 1).

According to Chisti (2007) and Cenciani et al. (2011) in the present study the production of the three cultivated microalgae biomass (especially Spirulina platensis) in large scale by using vinasse medium, is one of the issues concerning the oil supply for the production of biodiesel.

According to Jiang et $\boldsymbol{a l}$. (2012) the high concentration of $\mathrm{Ca}, \mathrm{Mg}, \mathrm{K}$ and $\mathrm{PO}_{4}$ in the vinasse make this useful byproduct as a fertilizer in all soil types besides as cultivation medium for algal biomass production. This was in agreement with the present results since, the contents of $\mathrm{Ca}, \mathrm{Mg}, \mathrm{Na}, \mathrm{K}, \mathrm{NH}_{3}, \mathrm{NO}_{3}$ and $\mathrm{PO}_{4}$ in the digested vinasse were high.

\section{Conclusion:}

The use of wastes and wastewaters to cultivate algae could reduce fresh water demand, nutrient costs and the need to waste remediation. So vinasse from sugarcane molasses fermentation was shown to be an alternative nutrient source for the cultivation of microalgae (Chlorella vulgaris, Spirulina platensis and Nostoc commune). The use of vinasse in the formulation of culture media may reduce production costs due to the use of organic residues as a cheap nutrient sources.

The use of vinasse as nutrient source may generate a high value added product such as protein and contribute to the resolution of the problem of dealing with distilleries byroducts. Vinasse as an industrial waste is being a problem for getting disposed from sugar industries (Hawamdyia). The large amount of vinasse can harm the environment, causing salinization and river Nile pollution. Therefore, it was though useful to try overcoming the created problem using it in agriculture land.

The production of algal biomass (by using vinasse) is intended to be used for many purposes such as production of single cell protein, carotenoids, chlorophyll, enzymes, esters, 
antibiotics, vitamins, hydrocarbons, extraction of pigments, animal feed, food supplement and in bioremediation of contaminated areas.

Also the biomass rich in lipids and fatty acids in large-scale is one of the issues concerning the oil supply for some use as biodiesel. The oil yield per hectare in some strains of microalgae is considerably higher than the most conventional crops such as oil palm, Jatropha, soybean and coconut. Oils found in microalgae cells show some physical and chemical properties similar to those of vegetable oils and therefore, can be considered a potential raw material for the production of biodiesel.

According to some authors as ethanol production increases, the vinasse production increases as well. The vinasse is a nutrient-rich byproduct originated from sugarcane manufacture for producing ethanol. For each liter of ethanol, ten to eighteen liters of vinasse are produced with variable composition. It cannot be discharged into watercourses as it results in death of fish and other aquatic biota.

Molasses which is a byproduct of the sugar industry can be also used as fuel, because it is cheaper to produce ethanol than oil chemically much less polluting than conventional fuels and does not produce toxic carbon during consumption, also for production of vinasse, antibiotic, organic acids and commercial yeasts for baking.

\section{References:}

Abdo, M.H.; Sabae, S.Z.; Haroon, B.M.; Refaat, B.M. and Mohammed, A.S. (2010): PhysicoChemical Characteristics, Microbial Assessment and Antibiotic Susceptibility of Pathogenic Bacteria of Ismailia Canal Water, River Nile, Egypt. Journal of American Science; 6(5):234-250. (ISSN: 1545-1003).

Andrade, M.R. and Costa, J.A.V. (2007): Mixotrophic cultivation of microalga Spirulina platensis using molasses as organic substrate. Aquaculture 264, 130-134.

Andres, F.; Barajas-Solano; Angel, D. Gonzalez-Delgado; Kafarov, V. (2014): effect of thermal pre-Treatment on Fermentable Sugar Production of Chlorella vulgaris. Chemical engineering Transactions. Vol. 37, 2014.

APHA (American Public Health Association) (1995): Standard methods for the examination of water and wastewater $19^{\text {th }}$ ed. American Public Health Assoc., American water Works Association, and Water Environment Federation. Fifteenth Street, N.W. Washington, D.C.

Arafat, S. and Yassen, A. (2002): Agronomic evaluation of fertilizing efficiency of vinasse. Symposium no. 14, Paper no. 1991, Pages: 1-6.

Armengol, J. E.; Lorenzo, R. and Fernández, N. (2003): Use of vinasse dilutions in water as an alternative for improving chemical properties of sugar cane planted vertisols 
Cultivos Tropicales, vol. 24, núm. 3, pp. 73-76, Instituto Nacional de Ciencias Agrícolas Cuba.

ASTM (American Standard Test Methods) (2007): American society for testing and materials. ASTM International, United States.

Banerjee, A.; Sharma, R.; Chisti, Y. and Banerjee, U.C. (2002): Botryococcus braunii: A renewable source of hydrocarbons and other chemicals. Crit. Rev. Biotechnol., 22: 245-279.

Becker, E.W. (2004): Microalgae in human and animal nutrition. In: Richmond a (ed) Handbook of microalgal culture: biotechnology and applied phycology, Blackwell Science, London, United Kingdom, pp. 312-351.

Becker, E.W. (2007): Micro-algae as a source of protein. Biotechnology. Adv. 25, 207-210.

Belay, A. (1997): Mass culture of Spirulina outdoors-the Earthrise farms experience. In: Vonshak, A. (Ed.), Spirulina platensis (Arthrospira) Physiology, Cell-Biology and Biotechnology. Taylor and Francis, London, pp: 131-158.

Benke, M.B.; Mermut, A.R. and Chatson, B. (1998): Carbon-13 CP/MAS NMR and DR-FTIR spectroscopic studies of sugarcane distillery waste. Can. J. Soil Sci. 78, 227-236.

Bezerra, R.; Montoya, E.Y.; Sato, S.; Perego, P.; de Carvalho, J.C. and Converti, A. (2011): Effects of light intensity and dilution rate on the semi continuous cultivation of Arthrospira (Spirulina) platensis: a kinetic Monod-type approach. Bioresour. Technol.102, 3215-3219.

Bischaffi , H. W. and Bold , H. C. (1963) : Physiological studies IV . Some soil algae from Enchanted rock and related algal species .Univ. Texas. Publ. N. 6318: 31-36.

Budiyono; Syaichurrozi, I.; Sumardiono, S. and Sasongko, S.B. (2013): Production of Spirulina platensis Biomass Using Digested Vinasse as Cultivation Medium. Trends Applied Sci. Res., 2013.

Cenciani, K.; Bittencourt-Oliveira, M. C.; Feigl, B. J. and Cerri, C. C. (2011): Sustainable production of biodiesel by microalgae and its application in agriculture. African Journal of Microbiology Research Vol. 5(26), pp. 4638-4645.

Cheunbarn, S. and Peerapornpisal, Y. (2010): Cultivation of Spirulina platensis using anaerobically swine wastewater treatment effluent. Int. J. Agric. Biol., 12: 586-590.

Chisti, Y. (2007): Biodiesel from microalgae. Biotechnol. Adv., 25: 294- 306.

Chisti, Y. (2008): Biodiesel from microalgae beats bioethanol. Trends Biotechnol., 26(3): 126131. 
Chojnacka, K. and Noworyta, A. (2004): Evaluation of Spirulina sp. growth in photoautotrophic, heterotrophic and mixotrophic cultures. Enzyme Microb. Technol. 34, 461-465.

Coca, M.; Barrocal, M.V.; Lucas, S.; González-Benito, G. and García-Cubero, M.T. (2014): Protein production in Spirulina platensis biomass using beet vinasse-supplemented culture media. Food Bioprod Process (2014), http://dx.doi.org/10.1016/j.fbp.2014.03.012

Coca, M.; Pe na, M. and González, G. (2005): Chemical oxidation processes for decolorization of brown colored molasses wastewater. Ozone Sci. Eng. 27, 365-369.

Cohen, Z.; Vonshak, A. and Richmond, A. (1987): Fatty-acid composition of Spirulina strains grown under various environmental conditions. Phytochemistry 26, 2255-2258.

Colla, L.M.; Reinehr, C.O.; Reichert, C. and Costa, J.A.V. (2007): Production of biomass and nutraceutical compounds bySpirulina platensis under different temperature and nitrogenregimes. Bioresour. Technol. 98, 1489-1493.

Converti, A.; Lodi, A.; Del Borgui, A. and Solisio, C. (2006): Cultivation of Spirulina platensis in a combined airlift-tubular reactor system. Biochem. Eng. J. 32, 13-18.

Danielo, O. (2005): An algae-based fuel. Biofutur., 255: 1-4.

Dayananda, C.; Sarada, R.; Bhattacharya, S. and Ravishankar, G.A. (2005): Effect of media and culture conditions on growth and hydrocarbon production by Botryococcus braunii. Process Biochem., 40: 3125- 3131.

Decloux, M. and Bories, A. (2002): Stillage treatment in the French alcohol fermentation industry. Int. Sugar J. 104, 509-517.

Dowd, M.K.; Johansen, S.L.; Cantarella, L. and Reilly, P.J. (1994): Low molecular weight organic composition of ethanol stillage from sugarcane molasses, citrus waste, and sweet whey. J. Agr. Food Chem. 42, 283-288.

Dubois, M.; Gilles, K.A.; Hamilton, J.K.; Repers, P.A. and Smith, F. (1956): Colorimetric method for determination of sugars and related substances. Analyt. Chem. 18: 350356.

FitzGibbon, F.; Singh, D.; McMullan, G. and Marchant, R. (1998): The effect of phenolic acids and molasses spent wash concentration on distillery wastewater remediation by fungi. Process. Biochem. 33, 799.

Fogg, G.E. and Thake, B. (1987): Algal Cultures and Phytoplankton Ecology. $3^{\text {rd }}$ Edn., The University of Wisconsin Press, USA., ISBN-13: 9780299105600, Pages: 269. 
Formagini, E.L.; Marques, F.R.; Serejo, M.L.; Paulo, P.L. and Boncz, M.A. (2013): the use of microalgae and their culture medium for biogas production in an integrated cycle. Water Science \& Technology In press, Uncorrected Proof (C) IWA Publishing 2013 | dol: $10.2166 /$ wst. 2013. 803.

Gallego-Blanco, J.; Munoz, E. and Hernandez-Rios, L. (2012): Effects of a vinassemicroorganism blend application on a Vertisol with sugarcane. Agronomic Colombiana 30(1), 116-123.

Gemtos, T.A., Chouliara, N. and Marakis, S.t. (1999): Vinasse rate, time of application and compaction effect on soil properties and durum wheat crop. Journal of Agricultural Engineering Research, 73: 283-296.

Guillard, R. R. L. (1978): Counting slides. A Sournia (Ed.) Phytoplankton Manual, UNESCO Paris, pp. 182-189.

Hadiyanto, M.M.A.N. and Hartanto, G.D. (2012): Enhancement of biomass production from Spirulina sp. Cultivated in POME medium. Proceedings of the International Conference on Chemical and Material Engineering, September 12-13, 2012, Semarang Indonesia, pp: 1-6.

Hase, R.; Oikawa, O.; Sasao, C.; Morita, M. and Watanabe, Y. (2000): photosynthetic production of microalgae biomass in a raceway system under greenhouse condition in Sendai City. J. Biosci. Bioeng. 89 (2), 157-163.

Jackson, M.L. (1973): Soil Chemical Analysis. Prentice-Hall., India.

Jiang, Z.; Li, Y.; Wei, G.; Liao, Q.; Su, T.; Meng, Y.; Zhang, H. and Lu, C. (2012): Effect of longterm vinasse application on physicochemical properties of sugarcane field soils. Sugar Tech. 14, 1-6.

Klekner, V. and Kosaric, N. (1992): Degradation of phenols by algae. Environ. Technol., 13: 493-501.

Leonard, D. and Lindley, N. D. (1999): Growth of Ralstonia eutropha on inhibitory concentrations of phenol: Diminished growth can be attributed to hydrophobic perturbation of phenol hydroxylase activity. Enzyme Microb. Technol., 25: 271-277.

Lodi, A.; Binaghi, L.; De Faveri, D.; Carvalho, J.C.M. and Converti, A. (2005): Fed-batch mixotrophic cultivation of Arthrospira (Spirulina) platensis (Cyanophycea) with carbon source pulse feeding. Ann. Microbiol. 55, 181-185.

Lowry, O.M.; Rosebrough, N.J.; Farr, L.A. and Randall, R.J. (1951): Protein measurements with folin phenol reagent. J. Biol. Chem. 193: 265-275. 
Markou, G. and Georgakakis, D. (2011): Cultivation of filamentous cyanobacteria (bluegreen algae) in agro-industrial wastes and wastewaters: a review. Appl. Energy 88, 3389-3401.

Matsudo, M.C., Bezerra, R.P.; Sato, S.; Perego, P.; Converti, A. and Carvalho, J.C.M. (2009): Repeated fed-batch cultivation of Arthrospira (Spirulina) platensis using urea as nitrogen source. Biochem. Eng. J. 43, 52-57.

Maynard, H.E.; Ouki, S.K. and Williams, S.C. (1999): Tertiary lagoons: A review of removal mechanisms and performance. Wat. Res, 33, 1-13.

Metzger, P. and Largeau, C. (2005): Botryococcus braunii: A rich source for hydrocarbons and related ether lipids. Appl. Microbiol. Biot., 66: 486- 496.

Meyer, J.; Rein, P.; Turner, P.; Mathias, K. and McGregor, C. (2011): good Management Practices Manual for the Cane Sugar Industry (Final). International Finance Corporation (IFC).

Mohana, S.; Acharya, B.K. and Madamwar, D. (2009): Distillery spent wash: treatment technologies and potential applications. J. Hazard. Mater. 163, 12-25.

Montenegro, S.; Menjivar, J.C.; Bonilla, C.R. and Madrinan, R. (2009): Influencia de la aplicacion de vinaza en actividad y bio-masa microbiana en un Entic Dystropept y un Fluventic Haplustool del Valle del Cauca, Colombia. Acta Agron. 58(1), 41-45.

Montenegro-Ferraz, C.A.; Aquarone, E. and Krauter, M. (1986): Utilization of by-products from alcoholic fermentation industry to biomass production of Spirulina maxima: Part II. Use of molasses alcohol distillate waste. Rev. Microbiol. 17, 15-21.

Ogbonna, J.C. and Tanaka, H.C. (1998): Cyclic autotrophic/heterotrophic cultivation of photosynthetic cells: A method of achieving continuous cell growth under light/ dark cycles. Bioresour. Technol., 65: 62-72.

Olguin, E.J. (2003): Phycoremediation: Key issues for cost-effective nutrient removal processes. Biotechnol Adv, 22: 81-91.

Olguin, E.J.; Galicia, S.; Angulo-Guerrero, O. and Hernandez, E. (2001): The effect of low light flux and nitrogen deficiency on the chemical composition of Spirulina $s p$ (Arthrospira) grown on digested pig waste. Bioresour. Technol. 77: 19-24.

Parnaudeau, V., Condom, N., Oliver, R., Cazevieille, P. and Rocous, S. (2007): Vinasse organic matter quality and mineralization potential, as influenced by raw material, fermentation and concentration processes. (C.F. Science direct- Bioresource Technology. Copyright 2007 Elsevier Ltd all rights reserved). 
Parnaudeau, V.; Condom, N.; Oliver, R.; Cazevieille, P. and Recous, S. (2008): Vinasse organic matter quality and mineralization potential as influenced by raw material, fermentation and concentration processes. Bio resource Technology, 99: 15531562 .

Patil, V.; Tran, K.H. and Giselrød, H.R. (2008): Towards sustainable production of biofuels from microalgae. Int. J. Mol. Sci., 9: 1188-1195.

Pérez, H.E.B. (2007): Biodiesel de microalgas - parte 1. Energia Verde - Biodiesel, MDL e Tecnologia em Microalgas., pp.1-19.

Pittman, J.K.; Dean, A.P. and Osundeko, O. (2011): The potential of sustainable algal biofuel production using waste water resources. Bioresour. Technol. 102, 17-25.

Quintero, D.R. (2008): Investigaciones sobre el manejo de las vinazas aplicadas al suelo. Cenicåa, Cali, Colombia.

Radmann, E.M.; Reinehr, C.O. and Costa, J.A.V. (2007): Optimization of the repeated batch cultivation of microalga Spirulina platensis in open raceway pond. Aquaculture 265, 118-126.

Ranga Rao, A.; Dayananda, C.; Sarada, R.; Shamala, T.R. and Ravishankar, G.A. (2007): Effect of salinity on growth of green alga Botryococcus braunii and its constituents. Bioresour. Technol., 98: 560-564.

Richmond, A. and Grobbelaar, J.U. (1986): factors affecting the output rate of Spirulina platensis with reference to mass cultivation. Biomass, 10: 253-264.

Ruiz-Marín, A.; Mendoza-Espinosa, L.G. and Stephenson, T. (2010): Growth and nutrient removal in free and immobilized green algae in batch and semi-continuous cultures treating real waste water. Bioresour. Technol. 101, 58-64.

Sassano, C.E.N.; Gioielli, L.A.; Ferreira, L.S.; Rodrigues, M.S.; Sato, S.; Converti, A. and Carvalho, J.C.M. (2010): Evaluation of the composition of continuously cultivated Arthrospira (Spirulina) platensis using ammonium chloride as nitrogen source. Biomass Bioenergy 34, 1732-1738.

Satyawali, Y. and Balakrishnan, M. (2008): Wastewater treatment in molasses-based alcohol distilleries for COD and color removal: a review. J. Environ. Manage. 86, 481-497.

Sawayama, S.; Minowa, T. and Yokoyama, S.Y. (1999): Possibility of renewable energy production and $\mathrm{CO}_{2}$ mitigation by thermochemical liquefaction of microalgae. Biomass Bioenerg., 17: 33-39. 
Scragg, A.H. (2006): the effect of phenol on the growth of Chlorella vulgaris and Chlorella VT-1. Enzyme Microb. Technol., 39: 796-799.

Semple, K.T. and Cain, R.B. (1997): Degradation of phenol and its methylated homologues by Ochromonas danica. FEMS Microbial. Lett., 152: 133-139.

Sheehan, J.; Camobreco, V.; Duffield, J.; Graboski, M. and Shapouri, H. (1998): A look back at the U.S. Department of Energy's Aquatic Species Program - Biodiesel from Algae. National Renewable Energy Laboratory. NREL/TP-580-24190.

Silva, M.A.S. (2009): Fertirrigação com vinhaça: impactos ambientais. Coleção Expressão Acadêmica, 1. Editora UFG, Goiânia, P. 109.

Singh, N. and Patel, D. (2012): Microalgae for Bioremediation of Destillery Effluent. Farming Food Water Security, Sustainable Agriculture Reviews 10: 83-109, DOI 10.1007/97894-007-4500-1_4.

Singh, N.K. and Dhar, D.w. (2006): Sewage effluent: a potential nutrient source for microalgae. Proc Indian Natl Sci Acad, 72: 113-120.

Soobadar, A. and Ng Kee Kwong, K.F. (2012): Impact of high rates of vinasse on some pertinent soil characteristics and on sugarcane yield in Mauritius. Journal of Sustainable Agriculture, 36 (1): 36-53.

Spolaore, P.; Joannis-Cassan, C.; Duran, E. and Isambert, A. (2006): Commercial applications of microalgae. J. Biosci. Bioeng., 101: 87- 96.

Sreedevi, M. G. (2007): Pollution Routing in a Tropical Estuarine Environment Thesis submitted in partial fulfilment of the requirements for the award of Doctor of Philosophy in Oceanography. Department of Physical Oceanography Cochin University of Science and Technology Kochi - 682 016, India. February 2007.

Tejada, M.A.G. (2010): Use of vinasse for soil reclamation and its impact on elemental loads in vertisol soil and groundwater. Proceedings of International Society of Sugarcane Technologists, (CD-ROM), 27: 7p.

Tejada, M.A.G. and Gonzalez, J.L. (2005): Beet vinasse applied to wheat under dry land conditions affects soil properties and yield. European Journal of Agronomy, 23: 336347.

Travieso, L.; Benitez, F. and Dupeyrón, R. (1999): Algae growth potential measurement in distillery wastes. Bull. Environ. Contam. Toxicol. 62, 483-489.

Travieso, L.; Benitez, F.; Sanchez, E., Borja, R.; Leon, M.; Raposo F.; Rincon, B. (2008): Performance of a Laboratory-scale Microalgae Pond for Secondary Treatment of Distillery Wastewater. Chem. Biochem. Eng. 22(4): 467-473. 
Troccon, J.L. and Demarquilly, C. (1989): Sugar beet molasses fermentation residues for ruminants. Prod. Anim. 2, 245-248.

Valderrama, L.T.; Del Campo, C.M.; Rodríguez, C.M.; de Bashana L.E. and Bashan, Y. (2002): Treatment of recalcitrant waste water from ethanol and citric acid production using the microalga Chlorella vulgaris and the macrophyte Lemna minúscula. Water Res. $36,4185-4192$.

Víctor M. B.; Garci'a-Cubero, M.T.; lez-Benito, G.G. and Coca, M (2010): Production of biomass by Spirulina maxima using sugar beet vinasse in growth media, New Biotechnology_ Volume 27, Number 6.

Wagner, L. (2007): Biodiesel from algae oil. Research report. Mora Associates Ltda, July.

Zarrouk, C. (1966): Contribution a I, etude d, une cyanophycée . Influence de divers facteurs physigques et chimiques sur la croissance et la photosynthése de Spirulina maxima . Geither, Ph. D. Thesis, Univ. of Paris, France. 


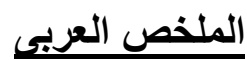

إنتاج كتلة حيوية من الطحالب باستخدام الفيناس كبيئة للنمو.

$$
\text { وفاء صبحى أبو الخير- عفاف حسن فرج - شيماء عبد القادر }
$$

قسم علم النبات، كلية البنات، جامعة عين شمس ، القاهرة، مصر.

الطحالب المجهرية أحد مصادر الغذاء المحتملة في المستقبل. ودرس العديد من الباحثين إمكانية استخدام المياه المستعطلة سابقا كبيئة لزراعة الطحالب المجهرية، ولكن استخدام الفيناس الناتج من الصناعات القائمة على قصب السكر كبيئة لزراعة الطحالب لم يأخذ مداه بعد. وكان الغرض من هذه

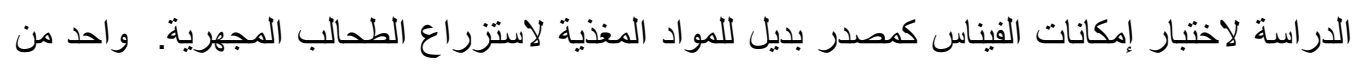
سلالة نقية من الطحالب الخضراء (Chlorella vulgaris) و اثثين من سلالات نقية من الطحالب الخضراء الزرقاء (Spirulina platensis \& Nostoc commune) استخدمت لهذا الغرض. كانت تزرع الطحالب المجهرية الثلاثة في ستة تركيزات مختلفة من الفيناس من ا +. . في المائة إلى س...

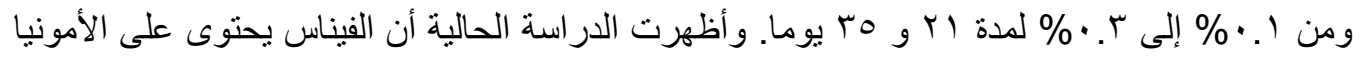

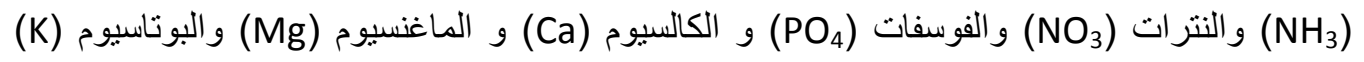
و الصوديوم (Na) و الموصلية الإكترونية بنسب عالية (EC). و قد لوحظ أعلى إنتاجية للكتلة الحيوية

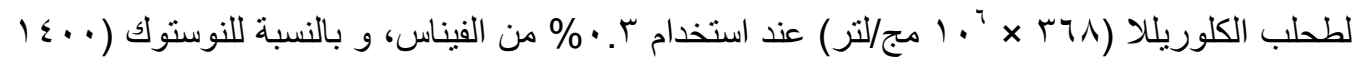

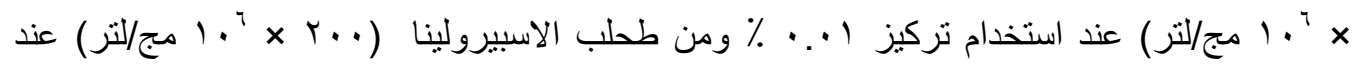

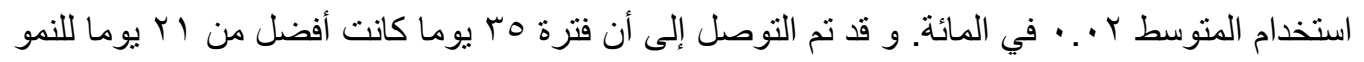

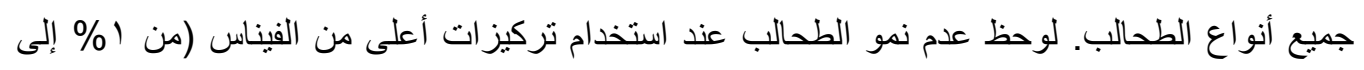
†\%). النتائج الحالية تظهر أنه من المكن استزراع الطحالب المجهرية مع منتج صناعة قصب السكر (الفيناس) عن طريق الهضم اللاهو ائي. 